\title{
Major challenges of integrating agriculture into climate change mitigation policy frameworks
}

\author{
Thomas Fellmann $^{1} \cdot$ Peter Witzke $^{2}$ - Franz Weiss ${ }^{3}$. \\ Benjamin Van Doorslaer ${ }^{1}$ - Dusan Drabik ${ }^{4}$. \\ Ingo Huck $^{1}$ - Guna Salputra ${ }^{1}$ - Torbjörn Jansson ${ }^{5}$ • \\ Adrian Leip ${ }^{3}$
}

Received: 24 August 2016 / Accepted: 17 March 2017 /Published online: 12 April 2017

(C) The Author(s) 2017. This article is published with open access at Springerlink.com

\begin{abstract}
Taking the European Union (EU) as a case study, we simulate the application of non-uniform national mitigation targets to achieve a sectoral reduction in agricultural noncarbon dioxide $\left(\mathrm{CO}_{2}\right)$ greenhouse gas $(\mathrm{GHG})$ emissions. Scenario results show substantial impacts on EU agricultural production, in particular, the livestock sector. Significant increases in imports and decreases in exports result in rather moderate domestic consumption impacts but induce production increases in non-EU countries that are associated with considerable emission leakage effects. The results underline four major challenges for the general integration of agriculture into national and global climate change mitigation policy frameworks and strategies, as they strengthen requests for (1) a targeted but flexible implementation of mitigation obligations at national and global level and (2) the need for a wider consideration of technological mitigation options. The results also indicate that a globally effective reduction in agricultural emissions requires (3) multilateral commitments for agriculture to limit emission leakage and may have to (4) consider options that tackle the reduction in GHG emissions from the consumption side.
\end{abstract}

Keywords Agriculture $\cdot$ Climate change $\cdot$ Emissions $\cdot$ Mitigation $\cdot$ Policy

Thomas Fellmann

thomas.fellmann@ec.europa.eu

1 European Commission, Joint Research Centre, Directorate Sustainable Resources, Seville, Spain

2 EuroCARE, Bonn, Germany

3 European Commission, Joint Research Centre, Directorate Sustainable Resources, Ispra, Italy

4 Agricultural Economics and Rural Policy Group, Wageningen University, Wageningen, The Netherlands

5 Department of Economics, Swedish University of Agricultural Sciences, Uppsala, Sweden 


\section{Introduction}

In anticipation of the conclusion of the Paris Agreement on Climate Change, countries were asked to submit Intended Nationally Determined Contributions (INDCs) for climate action to the United Nations Framework Convention on Climate Change (UNFCCC). The agreement legally entered into force on 4 November 2016 after the threshold requirements were met. Although specific modalities and procedures still have to be negotiated, the INDCs are set to become Nationally Determined Contributions (NDCs) and will form the basis for implementation for the parties that ratified the Paris Agreement. As of October 2016, 162 INDCs were submitted, representing a total of 189 countries as the European Union (EU) submitted a single INDC for all of its 28 member states. Agriculture is mentioned in 121 countries as one of the sectors where emission reductions are intended, but so far only a few of them set quantitative targets for agriculture (Richards et al. 2016; UNFCCC 2016).

The agricultural sector is a large contributor of non-carbon dioxide $\left(\mathrm{CO}_{2}\right)$ greenhouse gas (GHG) emissions, namely methane $\left(\mathrm{CH}_{4}\right)$ and nitrous oxide $\left(\mathrm{N}_{2} \mathrm{O}\right)$ from livestock, manure management, fertilizer use, rice (Oryza) cultivation, agricultural soils, burning of crop residues and savannahs. Agriculture contributes between 10 and $12 \%$ of global GHG emissions (Smith et al. 2014). ${ }^{1}$ Figure 1 shows that China (13.4\%), India (12\%), Brazil (8.5\%), the United States of America (USA) (6.8\%) and the aggregated 28 member states of the EU (7.7\%) together account for almost $50 \%$ of global agriculture emissions. However, from the EU, only France $(1.3 \%)$ and Germany $(1.1 \%)$ belong to the 22 countries with a share exceeding $1.0 \%$ of global agriculture GHG emissions. On the other hand, with respect to the EU, France (19\%), Germany $(15 \%)$ and the UK (11\%) together account for about $45 \%$ of total EU agriculture emissions, with the next highest contributions from Spain, Poland and Italy ( $8 \%$ each).

Depending on the relative size and importance of the agricultural sector, the share of agriculture in total national GHG emissions varies substantially among countries. Analysing data from National Communications to the UNFCCC, Richards et al. (2015) found that on average, agriculture contributes about $30 \%$ to national GHG emissions (excluding emissions from land use, land use change and forestry (LULUCF)). This is higher than the estimated 10$12 \%$ contribution of agriculture to global emissions because of a large number of countries where agriculture emissions are relatively important in national GHG emissions even though they are rather small in absolute terms. In 42 low-income developing countries, agriculture contributes more than $50 \%$ to national emissions, whereas on average it is $35 \%$ in developing countries and $12 \%$ in developed countries (Richards et al. 2015). Figure 2 shows that in the major contributors to global agriculture emissions (presented in Fig. 1), the share of agriculture in national GHG emissions is quite diverse (e.g. $46 \%$ in Brazil, $23 \%$ in India, $11 \%$ in China and $8 \%$ in the USA). In the EU as a whole, agriculture contributes about $10 \%$ to total GHG emissions, but respective shares in the member states are also very diverse: the highest in Ireland $(31 \%)$ and the lowest in Malta $(2.5 \%)$.

Notwithstanding the diversity of the absolute and relative importance of agriculture emissions, recent scenario analyses indicate that reductions in agricultural emissions will be important for meeting ambitious global climate goals of limiting warming to 1.5 or $2{ }^{\circ} \mathrm{C}$

\footnotetext{
${ }^{1}$ According to the Common Reporting Format of the UNFCCC, the source category 'agriculture' covers the emissions of nitrous oxide and methane. Emissions (and removals) of carbon dioxide $\left(\mathrm{CO}_{2}\right)$ from land use, land use change and forestry (LULUCF) as well as $\mathrm{CO}_{2}$ emissions related to energy consumption at farm level (e.g. in buildings and machinery use) or to the processing of inputs (e.g. mineral fertilizers) are attributed to other sectors. In this paper, we focus only on the non- $\mathrm{CO}_{2}$ emissions from agriculture.
} 

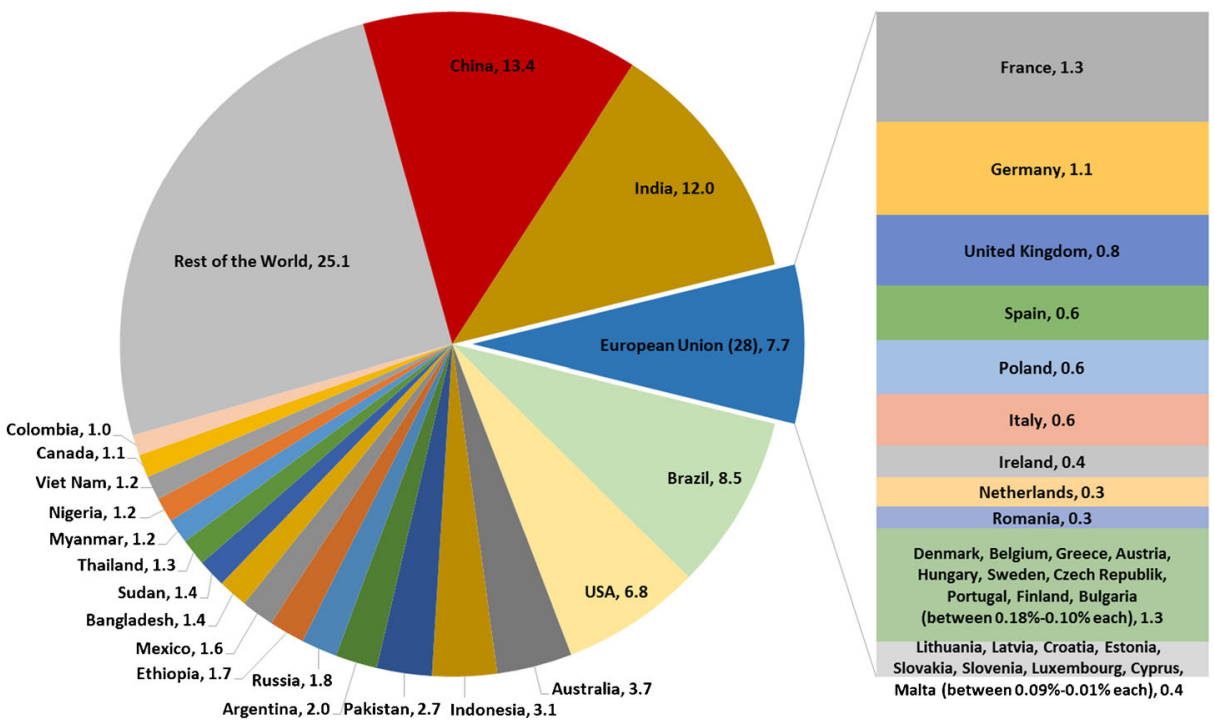

Fig. 1 Share in global agriculture GHG emissions (\%, 2012). Source: FAO (2016)

above pre-industrial levels (Reisinger et al. 2013; Gernaat et al. 2015; Wollenberg et al. 2016). Therefore, the Paris Agreement has put the agricultural sector back into focus when it comes to the fine-tuning of how countries achieve their overall emission reduction targets.

Against this background, the purpose of this paper is to highlight and discuss potential impacts and major challenges of integrating agriculture into national and international climate change mitigation policy frameworks and strategies. More precisely, we want to address two

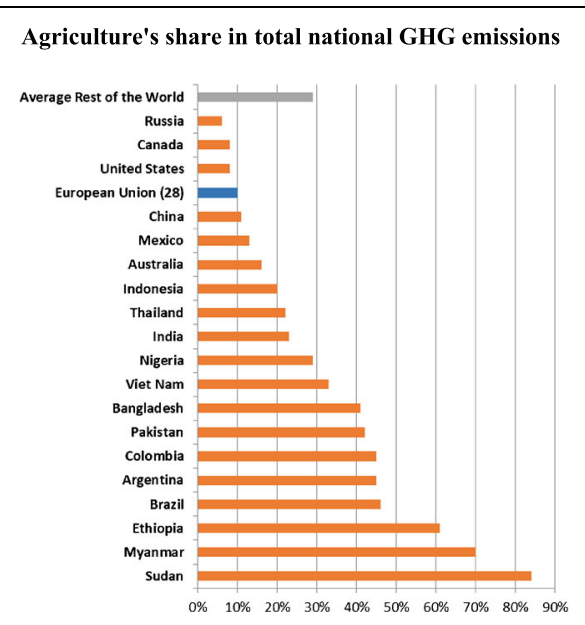

\section{Agriculture's share in total national GHG emissions in the EU Member States}

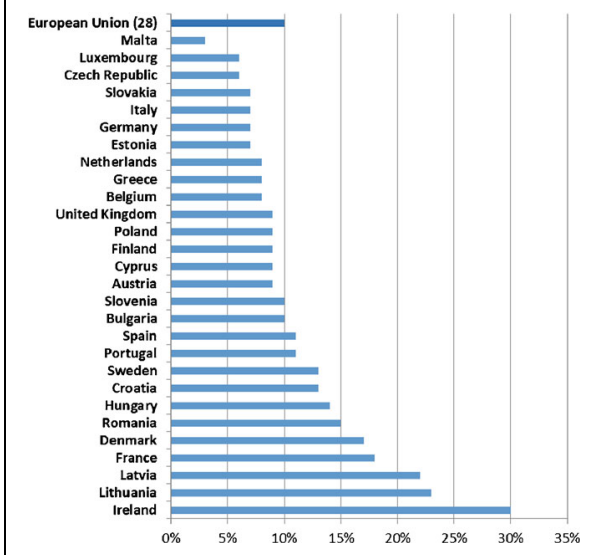

Fig. 2 Share of agriculture in total national GHG emissions (\%). The left panel depicts the countries with a share of at least $1.0 \%$ in global agriculture GHG emissions (cf. Fig. 1). Source: Own compilation based on data of Richards et al. (2015) 
questions: What would be the effects on production, prices, income, consumption, trade and emission leakage if countries rigidly applied national GHG mitigation targets onto their agriculture sector? What are the major challenges that have to be tackled for an efficient and effective emission reduction policy in the agriculture sector? To address these questions, we take the EU as case a study. There are at least two reasons for this selection: (i) the EU shows a very diversified structure of the absolute and relative importance of agricultural emissions within its member states, reflecting the respective global diversity indicated above and (ii) in its INDC, the EU committed to reducing GHG emissions by at least $40 \%$ by 2030 compared to 1990 levels (European Council 2014). Similar to most other parties to the Paris Agreement, specific EU legislative measures still have to be negotiated, including national mitigation targets for the member states and the specific way the agricultural sector will be included in the mitigation strategy. Therefore, we model an illustrative scenario that simulates a rigid implementation of nonuniform mitigation targets for EU agriculture according to a distribution key that is based on current national targets for the EU member states. Scenario results allow us to highlight and discuss key challenges significant not only for the EU but also relevant globally with respect to the integration of agriculture into national and global climate change mitigation strategies.

\section{Modelling approach and scenario setting}

For the quantitative analysis, we employ an adjusted version of the Common Agricultural Policy Regional Impact Analysis (CAPRI) modelling system. CAPRI is a large-scale economic comparative-static, global multi-commodity, agricultural sector model. The model is frequently used for assessing the impact of agricultural, environmental and trade policies on agricultural production, trade, prices and income as well as environmental indicators in a consistent framework. Although the model focuses on the EU (on regional, member state and aggregated EU level), it is a global model as it covers global bilateral trade for major agricultural commodities. CAPRI consists of two interacting modules: a supply module and a market module. The supply module comprises independent aggregate optimization models representing agricultural activities (28 crop and 13 animal activities) in all 273 Nomenclature of Territorial Units for Statistics (NUTS)2 regions within the EU. The market module consists of a spatial, global multi-commodity model for 47 primary and processed agricultural products, covering 77 countries in 40 trade blocks. The behavioural functions for supply, human consumption, feed and processing in the market module are all differentiated by commodity and geographical units and apply flexible functional forms so that calibration algorithms ensure full compliance with microeconomic theory. The link between the supply and market modules is based on an iterative procedure until an equilibrium is obtained (Britz and Witzke 2014; CAPRI 2016).

The regional supply models in CAPRI capture links between agricultural production activities in detail. Based on the inputs and outputs of these activities, agricultural GHG emissions are endogenously calculated according to the IPCC (2006) tier 2 method for the most important drivers. For activities where the respective information is missing, a tier 1 approach is applied to calculate GHG emissions (e.g. rice cultivation). The CAPRI reporting of agriculture GHG emissions mimics the reporting of emissions by the EU to the UNFCCC, that is, a Global Warming Potential (GWP) of 21 for methane and 310 for nitrous oxide is assumed. A more detailed description of the general calculation of agricultural emission inventories in CAPRI on activity level is given in Pérez Domínguez (2006), Leip et al. (2010) and Pérez Domínguez et al. (2012). 
In previous GHG mitigation policy analyses with CAPRI, technological (i.e. technical and management-based) mitigation options were not implemented endogenously. This paper draws on the first study to endogenize the choice among the following selected technological mitigation options (each of them can voluntarily be applied by farmers) within the CAPRI model (see Van Doorslaer et al. 2015): (1) farm scale anaerobic digestion, (2) community anaerobic digestion, (3) nitrification inhibitors, (4) improved timing of fertilization, (5) precision farming and (6) changes in the composition of animals' feed. The model allows the simultaneous use of different options, for example, nitrification inhibitors, the timing of fertilization and precision farming can be combined to reduce $\mathrm{N}_{2} \mathrm{O}$ emissions due to fertilizer applications. Implementation costs and mitigation potential of the modelled technological mitigation options are taken from the Greenhouse Gas and Air Pollution Interactions and Synergies (GAINS) database (GAINS 2013; Höglund-Isaksson et al. 2013). The level of production activities and the use of mitigation technologies are constrained by various factors, including land availability, fertilization requirements of the cropping systems versus organic nutrient availability, feed requirements in terms of dry matter, net energy, protein and fibre for each animal. Production activities and decisionmaking are also influenced by agricultural and environmental policy restrictions (Britz and Witzke 2014; CAPRI 2016). The next section provides more details on how mitigation options have been implemented into the CAPRI model.

Emission reductions in the EU may be linked to production decreases that can trigger increases in imports or decreases in exports. This can induce production increases in non-EU countries, leading to higher emissions in these regions (i.e. emission leakage). To estimate emission impacts outside the EU, a specific CAPRI module has been further developed to estimate emission factors for agricultural products for non-EU countries. The module applies fixed emission coefficient to agricultural production outside of the EU, as computed by the market model. The emission coefficients were estimated using time series data on agricultural production from the Food and Agriculture Organization Corporate Statistical Database (FAOSTAT) and emission inventories from the Emission Database for Global Atmospheric Research (EDGAR 2013). A robust estimator was developed within a Bayesian framework, using prior distributions for coefficients obtained from the bottom-up computation of emissions in the CAPRI supply model. Once estimated, the coefficients were fixed in simulations, thus permitting no endogenous response in emission intensity in a simulation. As for the calculation of EU agricultural emissions in this paper, we also consider only emissions of the UNFCCC category 'Agriculture' for the approach to quantifying emission leakage, that is, other emissions related to agricultural production, like, for example, emissions from land use change, are not covered (for a detailed description of the CAPRI emission leakage methodology see Jansson et al. 2010, Pérez Domínguez et al. 2012 and Van Doorslaer et al. 2015).

\subsection{The model set-up}

The regional income maximization is formulated as

$$
\begin{aligned}
& \max R(\text { act })-C^{\mathrm{T}}(\text { act, fert, feed, mshar }) \\
& \text { s.t. } \\
& G(\text { act, feed, fert }) \leq 0 \\
& 0 \leq \operatorname{mshar}_{a, m, e} \leq 1, \forall m \\
& \sum_{m} \operatorname{mshar}_{a, m, e}=1,
\end{aligned}
$$

where the regional indices are omitted and 
$R$ revenue function, combining sales from marketable outputs from production activities as well as premiums directly paid to activities,

$C^{\mathrm{T}}$ total cost function, combining cost elements directly related to activities, as well as purchases of marketable inputs (feed, fertilizer) and costs of mitigation efforts,

$G$ vector constraint function representing agricultural technology,

act vector of production activities with a certain intensity. Typical element: act $_{a}$,

$a$ set of production activities (e.g. dairy cows with high yield),

fert vector of mineral fertilizer purchases. Typical element: fert $_{n}$,

$n$ set of plant nutrients $(\mathrm{N}, \mathrm{P}, \mathrm{K})$,

feed matrix of feed input coefficients. Typical element: feed $\mathrm{a}_{a, f}$,

$f$ set of feed items (e.g. feed cereals),

mshar vector of mitigation shares. Typical element $\operatorname{mshar}_{a, m, e}$,

$m$ set of mitigation technologies (including 'no mitigation'),

$e$ set of emission types (e.g. $\mathrm{CH}_{4}$ from manure management).

The cost function is assumed to be separable into parts related to mitigation efforts and other costs

$$
\begin{gathered}
C^{\mathrm{T}}(\text { act, fert, feed, mshar })=\sum_{a} \operatorname{act}_{a} \sum_{m, e} C^{m}\left(\operatorname{mshar}_{a, m, e}\right)+\text { fert }_{N} \sum_{m} C^{m}\left(\operatorname{mshar}_{N, m, \mathrm{~N}_{2} \mathrm{Omin}}\right), \\
+C^{O}(\text { act, fert, feed })
\end{gathered}
$$

where

$C^{m}$ mitigation cost per activity level for mitigation option $m$, which depends on mitigation share mshar $_{a, m}$ for activity $a$, mitigation option $m$ and targeting emission type $e$,

$C^{O}$ other (non-mitigation) cost depending on activity level, feed coefficients and fertilizer quantities.

The mitigation shares do not enter the constraint function $\mathrm{G}($.$) nor the cost function C^{\mathrm{O}}$. In the case of anaerobic digestion (AD), a relevant mitigation technology targeting $\mathrm{CH}_{4}$, this seems to be largely correct, assuming the residues (containing the nitrogen and other plant nutrients from the manure and other feedstock for $\mathrm{AD}$ ) are returned to the soil without significant losses. The only effect of $\mathrm{AD}$ is then to reduce $\mathrm{CH}_{4}$ emissions from manure and to generate income (negative cost $C^{m}$ ). The assumption of no influence of mitigation on constraints and other costs is more questionable for measures to reduce $\mathrm{N}_{2} \mathrm{O}$ emissions from fertilizer application such as precision farming or improved timing of fertilization. These measures should also influence the overall nutrient balance in the crop sector, but this is currently neglected in our modelling approach.

Most emission types are calculated as the product of emission factors per activity level (determined as a function of yields and other characteristics) and activity levels. For some of them, mitigation measures may reduce emissions according to a factor $m f a c_{a, e}$ below the standard, uncontrolled amount ( $=100 \%)$. The most important example is the reduction in $\mathrm{CH}_{4}$ emissions from manure management according to the GAINS (2013) mitigation options farm scale and community scale anaerobic digestion plants. Formally,

$$
\begin{aligned}
& \mathrm{emi}_{e}=\sum_{a} \mathrm{mfac}_{a, e} \times \varepsilon_{a, e} \times \mathrm{act}_{a} \\
& \text { where } \\
& \operatorname{mfac}_{a, e}=\sum_{m} \mu_{a, m, e} \times \operatorname{mshar}_{a, m, e}
\end{aligned}
$$

and

$e m i_{e}$ emissions of type $e$, 
$\varepsilon_{\mathrm{a}, \mathrm{e}}$ uncontrolled emission factor for emission type $e$ from activity $a$,

$\mu_{\mathrm{a}, \mathrm{m}, \mathrm{e}}$ reduction factor for emission type $e$ from activity $a$, if a certain mitigation technology $m$ were fully implemented (which may be infeasible).

Emissions of $\mathrm{N}_{2} \mathrm{O}$ from synthetic fertilizers are incorporated similarly with the total use of mineral fertilizer adopting the role of emissions causing activity. Relevant emission mitigation options are nitrogen inhibitors, timing of fertilization and precision farming, as defined in the GAINS model (the mitigation technologies can also be combined)

$$
\begin{aligned}
& \operatorname{emi}_{\mathrm{N}_{2} \mathrm{Omin}}=\operatorname{mfac}_{N, \mathrm{~N}_{2} \mathrm{Omin}} \times \varepsilon_{N, \mathrm{~N}_{2} \text { Omine }} \times \text { fert }_{N} \\
& \text { where } \\
& \operatorname{mfac}_{N, \mathrm{~N}_{2} \mathrm{Omin}}=\sum_{m} \mu_{N, m, \mathrm{~N}_{2} \text { Omin }} \times \operatorname{mshar}_{N, m, \mathrm{~N}_{2} \mathrm{Omin}}
\end{aligned}
$$

Emissions from enteric fermentation per animal category are calculated according to IPCC tier 2 methods from animal numbers, feed intake in gross energy and methane conversion factor. In the CAPRI model, unlike the situation in inventory calculations envisaged by IPCC (2006), feed intake and its composition are known model variables. Therefore, it is possible to directly compute gross energy intake from the endogenous feed input coefficients and thereby capture the effects of endogenous changes in the feed mix on digestibility and emissions. Mitigation factors are applied as above, reflecting the saving of methane emissions if anaerobic digestion plants are used:

$$
\begin{aligned}
& \mathrm{emi}_{\mathrm{CH}_{4} e n}=\sum_{a} \mathrm{mfac}_{a, \mathrm{CH}_{4} e n} \times \operatorname{act}_{a} \times \sum_{f} \varepsilon_{a, f, \mathrm{CH}_{4} e n} \times \mathrm{feed}_{a, f} \\
& \text { where } \\
& \operatorname{mfac}_{a, \mathrm{CH}_{4} e n}=\sum_{m} \mu_{a, m, \mathrm{CH}_{4} e n} \times \operatorname{mshar}_{a, m, \mathrm{CH}_{4} e n}
\end{aligned}
$$

In summary, the objective of a CAPRI supply model is to maximize the net revenues as in Eq. (1), considering given parameters such as product prices and premiums paid under the EU's Common Agricultural Policy, as well as the costs for technological mitigation measures and other costs. Following an iterative procedure, the model obtains an equilibrium that reflects the optimum of production activities, mitigation technologies and feed use for a given emission target.

\subsection{Construction of the scenarios}

We construct a reference scenario (REF) and a mitigation policy scenario (HET28) to simulate a rigid implementation of mitigation targets for the EU agricultural sector. ${ }^{2}$ The simulation year for both scenarios is 2030 , and in both scenarios, farmers can voluntarily apply the abovementioned technological GHG mitigation options. The REF scenario assumes the status quo policy as scheduled in the current legislation based on the information available by mid-2015 (e.g. abolishing the milk and sugar quotas). The REF scenario relies on the agricultural market outlook of the European Commission (2012), which itself is based on the Agricultural Outlook of the Organization for Economic Cooperation and Development (OECD) and the Food and Agriculture Organization of the United Nations (FAO) (OECD-FAO 2012) and gives mediumterm projections up to the year 2022 in a consistent analysis framework by using also external

\footnotetext{
2 This paper draws on one of the scenarios of the 'Economic assessment of GHG mitigation policy options for EU agriculture' (EcAMPA 1) project. For more information on the project and further scenarios, see Van Doorslaer et al. (2015).
} 
sources for the assumptions on macroeconomic developments (like GDP growth, exchange rates, world oil prices and population growth). As the projection year for our analysis is 2030, we extrapolated and supplemented the European Commission's projections with other information to arrive at the CAPRI REF results for the year 2030 (for more information on the CAPRI baseline process, see Himics et al. 2014).

With respect to GHG emission mitigation obligations, the EU agricultural sector is included under the Effort Sharing Decision (ESD) within the '2020 Climate and Energy Package' of the EU (European Council 2009). In this ESD, the EU member states have non-uniform GHG emission mitigation targets based on the relative gross domestic product (GDP) per capita. However, the mitigation targets are specific to the member states, but not individual sectors, and up to now, no explicit policy measures have been implemented to force GHG emission abatement in the agriculture sector. Therefore, no mitigation targets are applied in the REF scenario.

The mitigation policy scenario (HET28) follows the general setting of the REF scenario but aims at an EU-wide reduction in agricultural non- $\mathrm{CO}_{2}$ emissions of $28 \%$ in the year 2030 compared to 2005. The $28 \%$ reduction target is in line with the European Commission's roadmap for moving to a low-carbon economy in 2050 and an accompanying impact assessment (European Commission 2014a, b). It has to be noted that in the new '2030 Climate and Energy Framework' of the EU, submitted as INDC to the UNFCCC, agriculture emissions are again covered in an ESD, but targets for the member states for 2030 are still under discussion (European Council 2014). For our HET28 scenario, we, therefore, use mitigation targets for 2030 that are based on national targets of the current EU ESD (European Council 2009). The current ESD aims at a total EU GHG reduction of $20 \%$ by 2020 compared to 2005 emission levels. However, the ESD covers several sectors and applying the specific member states targets just to agriculture would translate to a total reduction in EU agriculture emissions by only $9 \%$. Therefore, we increase the member states mitigation targets according to a linear modification (ESD $-19 \%$ ), such that a $28 \%$ reduction in agricultural non- $\mathrm{CO}_{2}$ emissions is achieved at the aggregated EU level (Table 1). The corresponding emission reduction obligations are set per EU member state and NUTS2 region. The CAPRI model structure and the implementation of the mitigation scenario are depicted in Fig. 3.

\section{Scenario results}

Figure 4 presents the decomposition of the EU agriculture GHG emission developments under the REF and HET28 scenarios. The REF scenario shows agriculture's GHG emissions with no specific emission reduction requirements in place, indicating that by 2030 agriculture emissions in the EU are almost equal to the levels of $2005(+0.2 \%)$. This is especially notable when considering that between 1990 and 2012 the sector experienced a rather steady downward trend of $-24 \%$ (compared to $-19 \%$ for total EU emissions, excluding LULUCF). This historical decrease is mainly attributable to reductions in livestock numbers and productivity increases, as well as the implementation of agricultural and environmental policies (Van Doorslaer et al. 2015). The REF scenario projection suggests that agriculture emissions would plateau in 2030, which is a result of the general policy and technology developments and a favourable agricultural market environment. However, results are quite diverse among the member states. Agriculture emissions decrease most in Greece (-12\%), Romania (-11\%), Italy and Hungary ( $-5 \%$ each), whereas eight member states show increasing emissions, with highest increases indicated for Bulgaria and Latvia (both about $+20 \%$ ) and Portugal $(+16 \%)$. 
Table 1 GHG emission reduction target for agriculture in the EU member states in 2030 compared to 2005, as assumed in the HET28 scenario

\begin{tabular}{clll}
\hline Member state(EU-15) $^{\mathrm{a}}$ & Agricultural emission target & Member state(EU-N12) & Agricultural emission target \\
\hline Austria & -35 & Bulgaria & +1 \\
Belgium-Lux. & -34 & Cyprus & -24 \\
Denmark & -39 & Czech Republic & -10 \\
Finland & -35 & Estonia & -8 \\
France & -33 & Hungary & -9 \\
Germany & -33 & Latvia & -2 \\
Greece & -23 & Lithuania & -4 \\
Ireland & -39 & Malta & -14 \\
Italy & -32 & Poland & -5 \\
Netherlands & -35 & Romania & 0 \\
Portugal & -18 & Slovak Republic & -6 \\
Spain & -29 & Slovenia & -15 \\
Sweden & -36 & & -28 \\
UK & -35 & EU & \\
\hline
\end{tabular}

The member state targets are based on the current EU Effort Sharing Decision (European Council 2009), increased according to a linear modification (ESD -19\%) such that a $28 \%$ reduction in total EU agricultural non- $\mathrm{CO}_{2}$ emissions is achieved

${ }^{\text {a }}$ EU-15: 15 EU member states before 2004

${ }^{b}$ EU-N12: 12 EU member states of the 2004 and 2007 enlargements (Croatia has not been included in the analysis)

The emission reductions at member state level in the HET28 scenario should be seen in the context of the emissions in the REF scenario and the emission reduction obligation a member state faces according to the modelled policy (as indicated in Table 1). By scenario design, the $28 \%$ reduction target for EU agriculture emissions is met, and also each member state (at least)

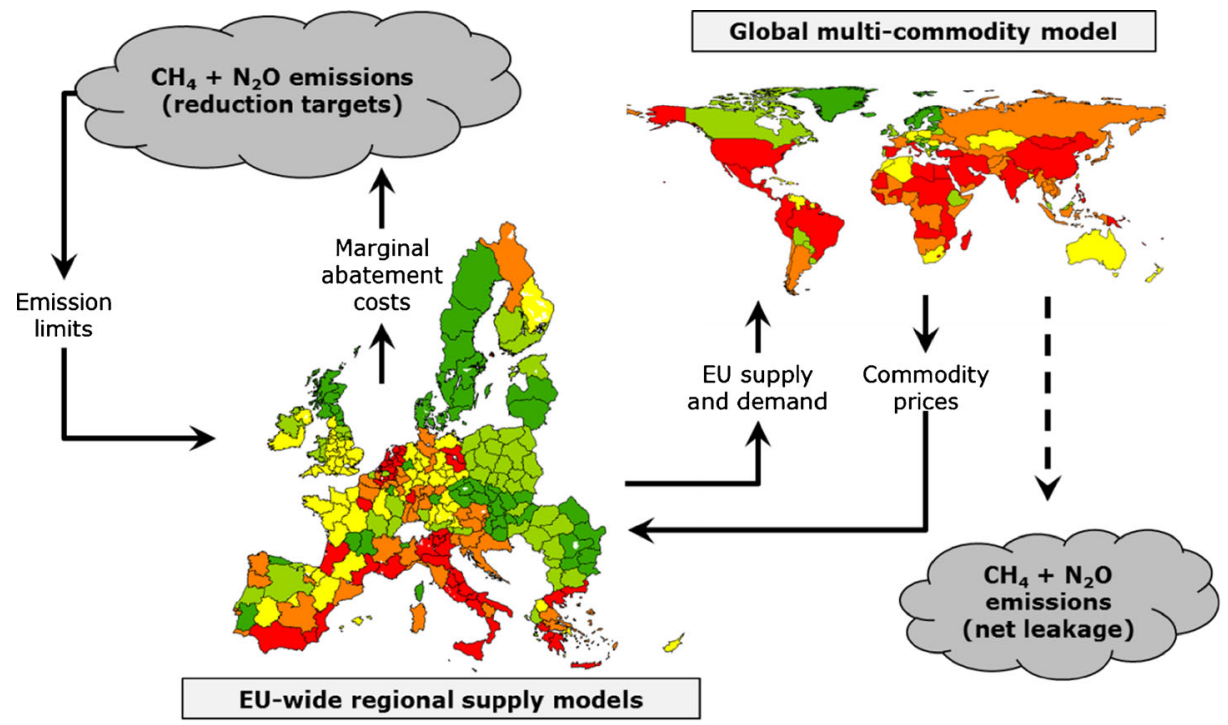

Fig. 3 CAPRI model structure and implementation of the mitigation policy scenario. Source: Adjusted from Pérez Domínguez and Fellmann (2015) 


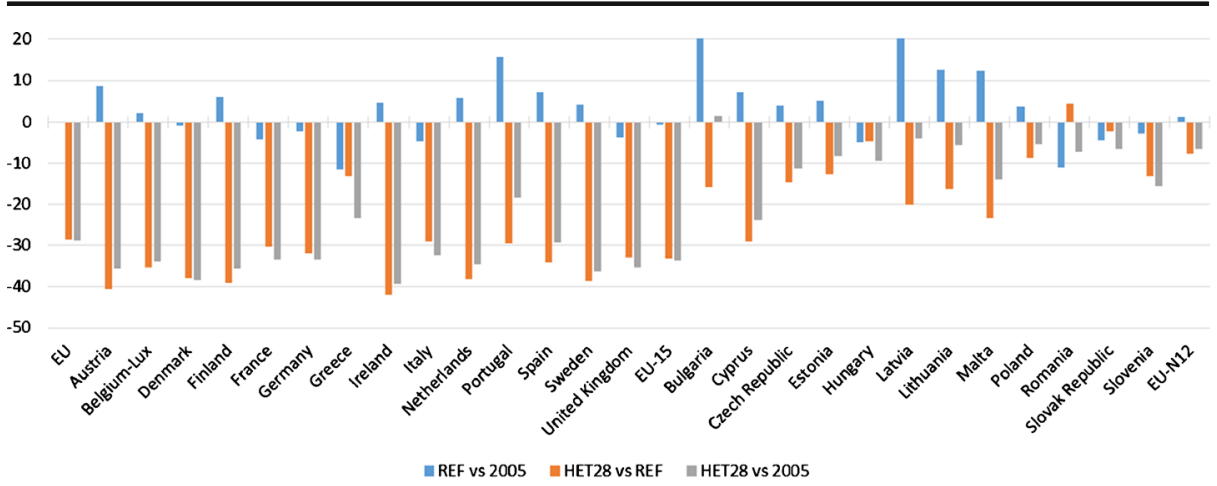

Fig. 4 Percentage changes in agriculture GHG emissions per EU member state (2030). The year 2005 is an expost simulation close to the historical 2005 data. EU-15: 15 EU member states before 2004 and EU-N12: 12 EU member states of the 2004 and 2007 enlargements

meets its respective national mitigation targets. In the following sections, we outline how the EU mitigation obligations affect agricultural production, prices, income, trade, consumption and emissions leakage.

\subsection{Impact on EU agricultural production, prices and income}

Figure 5 presents how agricultural activities in the EU are affected in scenario HET28 compared to REF. Most of the adjustments to the GHG mitigation obligation are made through lower activity levels (i.e. decreases in animal numbers, hectares and related supply), with largest reductions projected for the livestock sector, particularly beef meat production. Decreases in area and animal numbers are generally bigger than the decreases in supply, indicating productivity increases per animal and area (least productive areas and livestock are likely to be taken out of production first). Except set aside and fallow land, which is projected to increase by more than $17 \%$, the agricultural area is decreasing for all crops, leading to a total decrease in utilized agricultural area of $12 \%$. In the arable sector, fodder activities decrease the most, which is directly related to the decreases in the livestock sector, in particular to the reduction in the ruminant [namely beef cattle (Bos taurus), sheep (Ovis aries)

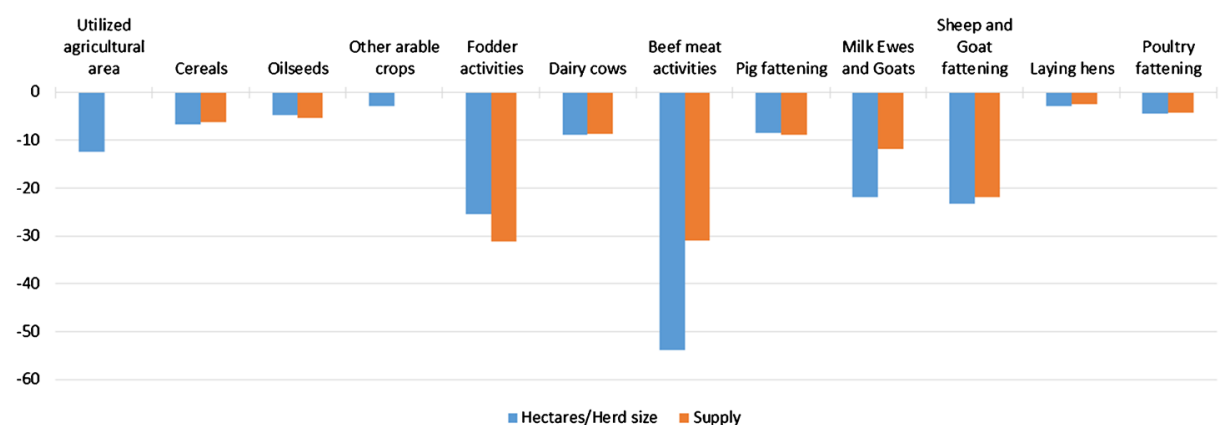

Fig. 5 Percentage change in EU area, herd size and supply in the HET28 scenario compared to REF (2030). Supply is not applicable for the aggregates of utilized agricultural area and other arable crops 
and goats (Capra hircus)] fattening activities. On the aggregated EU level, the number of beef cattle decreases by almost $54 \%$, and the impacts are most pronounced in those member states that are confronted with the highest mitigation obligations, such as Denmark (82\% reduction in beef herd size) and the Netherlands (76\%). The impact on dairy cows (Bos taurus) and production is less pronounced than on beef cattle and sheep and goat related activities, which can be attributed to a higher profitability of dairy cow production. Furthermore, the impact on pig (Sus domesticus) and poultry [namely chicken (Gallus gallus), turkey (Meleagris gallopavo), duck (Anas platyrhynchos) and goose (Anser anser domesticus)] fattening is also lower than on ruminant meet production, which is due to their lower emission intensities (i.e. lower GHG emissions per kilogramme meat).

The general production decrease results in higher producer and consumer prices in the EU in the scenario HET28 compared to REF (Fig. 6). The rise in producer prices is in line with the projected production decreases, showing highest price increases for beef meat $(+64 \%)$ and cow milk $(66 \%)$, and increases of about $11 \%$ for producer prices of cereals and oilseeds. Consumer price changes are of the same magnitude when looking at absolute changes, but due to high consumer margins (assumed constant), the relative changes are much lower. The relative increases in consumer prices for meat and dairy products vary between 10 and 30\%, whereas the impact on consumer prices for crops is below $1 \%$.

The production and price developments affect agricultural income. Total agricultural income takes into account the changes in the product margins (gross value added less cost) and in the production quantity of all agricultural activities. The scenario results indicate that in about $95 \%$ of the EU regions the increase in producer prices more than offset the income losses provoked by production decreases and increases in production costs. As a consequence, total agricultural income in the EU is projected to increase. However, the aggregated EU result hides large differences between the regions in the member states. Moreover, it has to be kept in mind that the CAPRI model applied is a market model, not a farm model, and therefore cannot depict structural change regarding the number of farmers. Given the large decreases in hectares and herd sizes, it is likely that some (especially smaller and less competitive) farmers would have to leave the sector if they are not able to cope with the rigid mitigation obligation implemented in the scenario. Evidently, only farmers remaining in the sector would benefit from potential income increases.

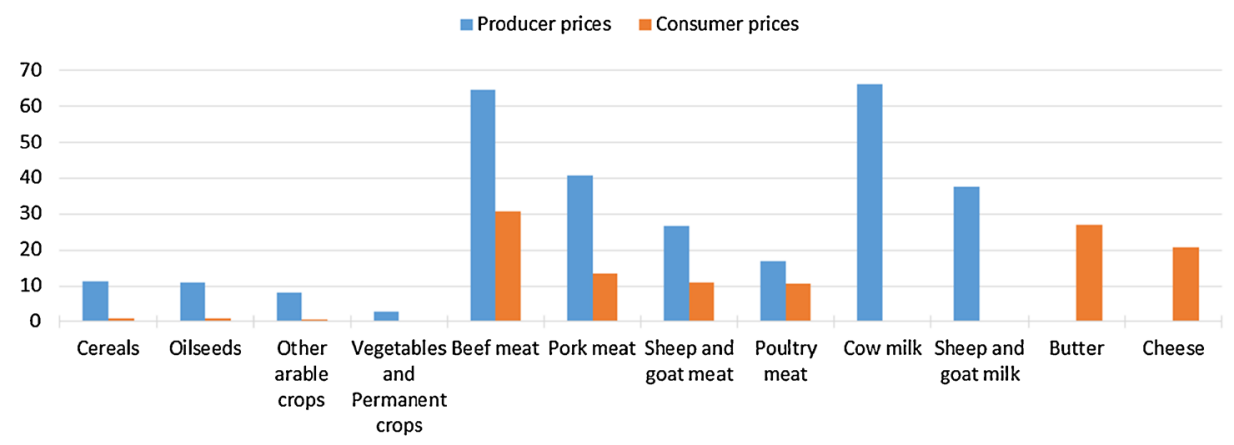

Fig. 6 Percentage change in EU producer and consumer prices in the HET28 scenario compared to REF (2030). The consumer price is not applicable for the milk aggregates, whereas the producer price is not applicable for dairy products (butter, cheese) 


\subsection{Impact on the EU trade balance, consumption and emission leakage}

The changes in EU production and prices lead to changes in the EU trade balance (exportsimports) as presented in Fig. 7. Regarding the EU's trade balance, it has to be noted that the scenarios are run under the assumption that current trade agreements and EU border protection mechanisms would stay in place by 2030. Following the large production drops in the EU, almost all agricultural EU exports decrease while at the same time imports increase, leading to a worsening of the EU trade balance of almost all agricultural products. As an exception, net imports are declining for oil cakes [the solids remaining after pressing oilseeds, namely soybean (Glycine max), rapeseed (Brassica napus) and sunflower seed (Helianthus annuus)], which is due to lower feed demand from the EU livestock sector. In line with the production developments, changes in EU imports and exports are more pronounced in the livestock than in the crop sector. EU beef meat imports are projected to increase by about 2 million tonnes (almost $360 \%)$. EU exports of pork $(-73 \%)$ and poultry meat $(-44 \%)$ decrease significantly, whereas the respective imports increase (although imports involve relatively small quantities). Moreover, the EU trade balance for dairy products weakens considerably, as especially the EU exports are significantly lower $(-31 \%)$ compared to the REF scenario.

As the increases in imports and the decreases in exports at least partly compensate for the reductions in EU production, the final impact of the GHG mitigation obligation on EU consumption appears to be of relatively lower magnitude (Fig. 8). The biggest consumption decrease is projected for dairy products (almost $-3 \%$ ), varying between $-2.5 \%$ for fresh milk products and $-7.5 \%$ for butter (not shown in the figure). Pork meat consumption is expected to decrease by more than $2 \%$, and beef meat as well as sheep and goat meat consumption by about $1 \%$. By contrast, consumers switch to poultry meat, which is less expensive and shows a consumption increase of more than $3 \%$. As a result, total EU meat consumption decreases by only $0.4 \%$. The decreases in the consumption of meat and dairy products seem to be compensated by increases in the food use of cereals $(+1.8 \%)$, and consumption increases of vegetable oils $(+1.8 \%)$, and fruits and vegetables $(+0.8 \%)$.

The changes in the EU trade balance in the HET28 scenario trigger production increases outside the EU, which in turn leads to an increase in agriculture emissions in non-EU countries and hence emission leakage. The effects of the HET28 scenario on global GHG emissions reveal that emission leakage may considerably downsize the net effect of EU mitigation targets on global GHG reduction. Given the model assumptions, the share of EU mitigated emissions offset by emission leakage may be as high as $91 \%$. The major part of emission leakage is

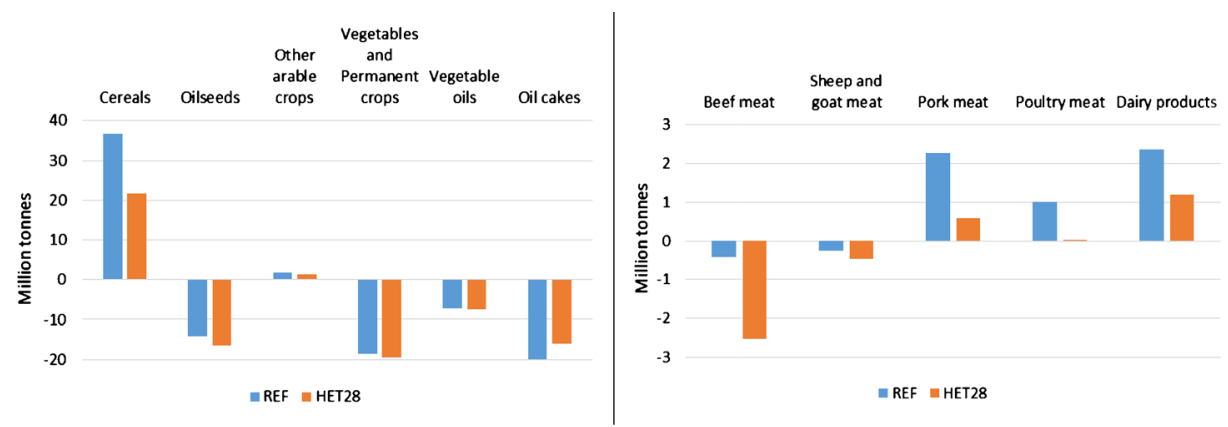

Fig. 7 EU trade balance in the REF and HET28 scenarios (2030). Trade balance = exports - imports 
caused by EU imports of animal products, with beef and other animal products being responsible for more than $90 \%$ of additional emissions outside the EU. According to CAPRI projections, the major part of emission increases outside the EU may happen in Africa, Asia and South America. This is because the EU grants free market access to developing countries in Africa and Asia and because the EU has established trade relations with South America.

\section{Discussion and conclusions}

The Paris Agreement on Climate Change puts the agricultural sector back into focus when it comes to the fine-tuning of how countries achieve their overall GHG emission reduction targets and the way agriculture will be included in national mitigation strategies. We take the EU as a case study and employ a revised version of the CAPRI model to run a reference scenario and an illustrative policy scenario for emission mitigation in agriculture. For the policy scenario, we simulate a rigid implementation of non-uniform mitigation targets for EU agriculture according to a distribution key that is based on augmented current (European Council 2009) national targets for the EU member states. The mitigation target is an EU-wide reduction in agricultural GHG emissions of $28 \%$ in the year 2030 compared to the year 2005 .

Results of the hypothetical policy scenario show important impacts on EU agricultural production, especially in the livestock sector. Compared to the reference scenario, results of the policy scenario show decreases in the EU cattle numbers of 54\%, and in crop and grassland area of up to $12 \%$ of the total utilized agricultural area. Crop production is directly affected by the GHG emission reduction obligations and indirectly by the reduced demand for feed from the livestock sector. The decreases in production levels lead to increases in EU agricultural producer prices that are projected to compensate for losses provoked by production decreases and increases in production costs, leading to an increase in total agricultural income at EU level. However, income changes show large regional differences and also some negative income impacts at regional level. Moreover, the model used is a market model and therefore does not account for structural change regarding the number of farms. It is likely that in the policy scenario some (especially smaller and less competitive) farmers would have to leave the sector if they are not able to cope with the GHG mitigation obligations; apparently, only farmers remaining in the sector would benefit from potential increases in total agricultural income. The drop in EU production causes substantially decreasing EU exports and increasing imports, which on the one hand leads to a deterioration of the EU trade balance, but on the

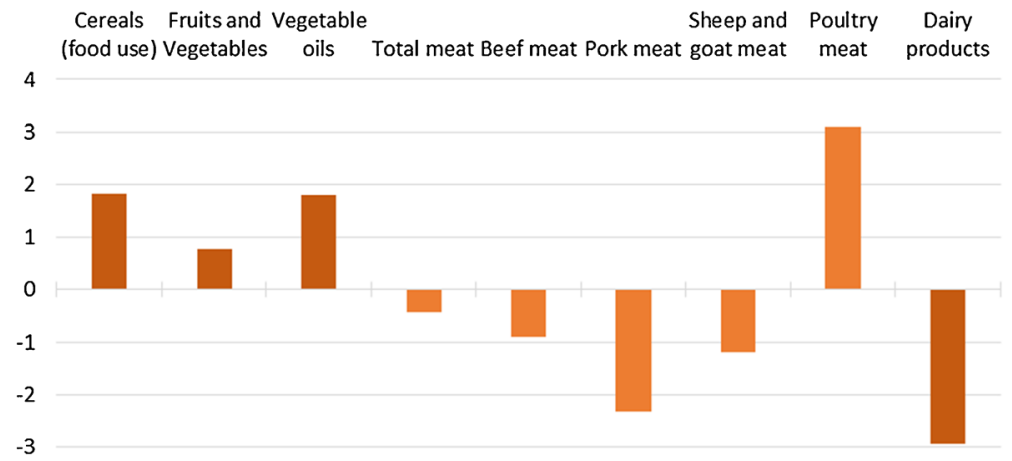

Fig. 8 Percentage change in EU consumption in the HET28 scenario compared to REF (2030) 
other hand, almost compensates for the EU production decreases. Therefore, EU consumption of agricultural products is only moderately affected; for example, total EU meat consumption decreases by only $0.4 \%$, with a slight shift from beef and pork meat consumption to the cheaper and less emission-intensive poultry meat. However, the changes in the EU trade balance induce increases in production and associated emissions in non-EU countries (emission leakage), which considerably downsizes the net effect of the EU mitigation effort.

Our mitigation scenario focuses on the EU, but, as outlined in the introduction, the diversified structure of relative and absolute importance of agricultural emissions within the EU and its member states reflects the respective diversity at the global level. Therefore, our scenario results identify four major challenges that are relevant not only to the EU but generally to all countries with respect to the integration of agriculture into national and global climate policy frameworks and mitigation strategies.

Challenge 1: Targeted but flexible implementation of mitigation obligations. Scenario results indicate that it would not be a good strategy if current national mitigation targets were taken as a benchmark to achieve a sectoral EU-wide reduction in agricultural emissions, as this could lead to adverse impacts on agricultural production in most member states and the EU a whole. Our modelling results can be interpreted as high-end estimates of the impacts of the modelled mitigation target for EU agriculture, as farmers are obliged to reduce emissions at the national and regional level, and no grade of flexibility is given regarding the mitigation targets per region. The scenario results suggest that a specific mitigation target for EU agricultural emissions might require a more flexible implementation, also taking into account where emissions are least costly to reduce. Such an approach would not lead to emission reductions according to national mitigation targets nor would it necessarily mean that most emissions would be reduced in those member states with highest absolute agriculture emissions. However, it could help to decrease adverse production effects at aggregated EU level while meeting a specific reduction target for EU agriculture emissions. In general, there is a wide heterogeneity in both mitigation potential and marginal abatement costs within the agricultural sector, not only in the EU but globally, differing between regions and emission sources, and often related to differences in production types and farm size (Vermont and De Cara 2010; MacLeod et al. 2015; Pérez Domínguez and Fellmann 2015; Henderson et al. 2017). A more flexible implementation of mitigation efforts, using market-based approaches, for example, allowing the trade of mitigation obligations among farmers and regions, are considered to diminish adverse effects on production levels (De Cara and Jayet 2011; Pérez Domínguez et al. 2012). Our scenario results suggest that such approaches should be thoroughly assessed before countries implement their mitigation strategies for the agriculture sector.

Challenge 2: Enhancing the application of technological mitigation options. For this analysis, a limited set of specific technological (i.e. technical and management-based) GHG mitigation options has been introduced into the modelling approach. In our mitigation scenario, almost all EU crop production would potentially use the provided mitigation options in 2030. On the other hand, based on the included set of options, the impact of a change in livestock production management and technology on overall EU agriculture emissions tends to be rather limited. As a consequence, the largest part of the required GHG reduction is realized by a quantitative adjustment of production (herd size, yield and cultivated hectares). A similar result is likely at global level if the mitigation targets were implemented worldwide. It has to be noted that the modelled set of technologies does not include all available technical and management-based mitigation options (e.g. feed additives to reduce methane emissions from enteric fermentation or genetic improvements steered to increasing milk yields of dairy cows 
are not modelled). Taking more options into consideration and assuming a wider applicability, say due to additional farm structure change or accelerated technological maturation, could potentially downscale any negative impacts on the EU's agricultural production and trade in our scenario (see, e.g. Witzke et al. 2014). The importance of technical and management-based options for the mitigation of agricultural emissions is also indicated in the international literature and seems to have particularly great potential for emissions reduction in developing countries (Henderson et al. 2017; Hristov et al. 2013; Smith et al. 2007, 2014). However, it might need specific incentives and support measures (e.g. investment support or training) to trigger and facilitate the implementation of mitigation technologies both within and outside the EU. Moreover, regarding the latter technology transfer may play an important role for emission mitigation, specifically for developing countries (Tilman et al. 2011; Somanathan et al. 2014; Stavins et al. 2014).

Challenge 3: Reducing emission leakage. Even though the EU meets its emission reduction target in our policy scenario, an estimate on emission impacts outside the EU shows that the projected EU production decreases go along with emission leakage (i.e. an increase of emissions in non-EU countries), which substantially decreases the global net effect of the EU emissions reduction. The rise in non-EU emissions is due to agricultural production increases triggered to compensate for increasing EU imports and decreasing EU exports. The extent of emission leakage and hence the net gain of national mitigation efforts for global GHG emission reduction depends significantly on the relative GHG efficiency (i.e. emissions per unit of output) of agriculture in the exporting countries compared to the importing country (Caro et al. 2014; Pérez Domínguez and Fellmann 2015; Scott and Barrett 2015). Theoretically, border adjustment measures, like tariffs on imports based on the amount of GHG emissions released in their production, could be a possibility to decrease emission leakage. However, the practical usefulness of such measures is often questioned with respect to their general appropriateness, compliance with rules of the World Trade Organization, and due to concerns about negative welfare effects especially for developing countries (Frankel 2008; Stavins et al. 2014). In any case, such measures might not be necessary if challenges 1 and 2 were successfully tackled, as this would decrease production displacement and hence emission leakage. Moreover, the extent of emission leakage apparently also depends on the commitments other countries make regarding their contributions to the Paris Agreement. It remains to be seen how the global climate agreement will be put into action, but so far, none of the (other) major agricultural trade and important non- $\mathrm{CO}_{2}$ emitting countries, like China, Brazil, USA, Australia and Russia, has submitted concrete commitments for the integration of its agricultural sector into binding emission targets (UNFCCC 2016). Our scenario results show that such (multilateral) commitments would not only be necessary in the light of emission leakage and global emission mitigation but also with respect to minimizing distortions to agricultural competitiveness arising from unilateral emission mitigation obligations.

Challenge 4: Tackling GHG emissions from the consumption side. Our simulation scenario focuses on agricultural emission reduction from the production side. Scenario results show that the mitigation target set within the EU and related production decreases would affect EU consumers via higher food prices, resulting mainly in a decrease in dairy consumption and a rather slight shift in meat consumption towards poultry meat. However, the consumer price effect is rather low, and human consumption is eventually not significantly affected as the decreased production in the EU is partially compensated for by agricultural and food imports, which in turn jeopardize the mitigation efforts in the EU due to emission leakage. This underlines that it might be necessary to take net imported emissions into account when setting 
national mitigation targets, which would generally introduce new opportunities for emission reduction strategies on a large scale (Chicco and Stephenson 2012; Scott and Barrett 2015). However, emission reduction targets under the UNFCCC are territory and producer-based, and it is rather unlikely that this approach will be changed shortly (Somanathan et al. 2014). Successfully addressing challenges 1 to 3 would decrease the need for major adjustments regarding consumption patterns. Nevertheless, our scenario results give a strong indication that an effective mitigation strategy to decrease GHG emissions from agriculture should also consider options that tackle the reduction from the consumption side, especially with regard to meat products. GHG emission levels are indeed significantly affected by diets, as protein sources from animals are generally related to higher emissions than vegetable protein sources (Davis et al. 2010), and the importance of a change in consumption patterns to meet stringent climate change targets is also emphasized in the literature (Stehfest et al. 2009; Garnett 2011; Berners-Lee et al. 2012; Hedenus et al. 2014; Stehfest 2014; Westhoek et al. 2014).

Our scenario analysis does not imply that agriculture should be let off the hook with regard to the mitigation of GHG emissions. However, the identified four major challenges need to be tackled to achieve an efficient and effective integration of agriculture into national and international climate change mitigation policy frameworks and strategies.

\section{Compliance with Ethical Standards}

Disclaimer The views expressed are purely those of the authors and may not in any circumstances be regarded as stating an official position of the European Commission.

Open Access This article is distributed under the terms of the Creative Commons Attribution 4.0 International License (http://creativecommons.org/licenses/by/4.0/), which permits unrestricted use, distribution, and reproduction in any medium, provided you give appropriate credit to the original author(s) and the source, provide a link to the Creative Commons license, and indicate if changes were made.

\section{References}

Berners-Lee M, Hoolohan C, Cammack H, Hewitt CN (2012) The relative greenhouse gas impacts of realistic dietary choices. Energy Policy 43:184-190

Britz W., Witzke P (2014) CAPRI model documentation 2014, http://www.capri-model.org/docs/capri documentation.pdf

CAPRI (2016) CAPRI Modelling System, http://www.capri-model.org/

Caro D, LoPresti A, Davis SJ, Bastianoni S, Caldeira K (2014) CH4 and N2O emissions embodied in international trade of meat. Environ Res Lette 9:114005

Chicco G, Stephenson PM (2012) Effectiveness of setting cumulative carbon dioxide emissions reduction targets. Energy 42:19-31

Davis J, Sonesson U, Baumgartner DU, Nemecek T (2010) Environmental impact of four meals with different protein sources: case studies in Spain and Sweden. Food Res Int 43(7):1874-1884

De Cara S, Jayet PA (2011) Marginal abatement costs of greenhouse gas emissions from European agriculture, cost effectiveness, and the EU non-ETS burden sharing agreement. Ecol Eco 70(9):1680-1690

EDGAR (2013): Emissions Database for Global Atmospheric Research, European Commission, Joint Research Centre, http://edgar.jrc.ec.europa.eu/index.php.

European Commission (2012) Prospects for Agricultural Markets and Income in the EU 2012-2022, DG Agriculture and Rural Development, http://ec.europa.eu/agriculture/markets-and-prices/medium-termoutlook/2012/fullrep_en.pdf. 
European Commission (2014a) A policy framework for climate and energy in the period from 2020 to 2030. Communication from the Commission to the European Parliament, the Council, the European Economic and Social Committee and the Committee of the Regions Communication [COM(2014) 15].

European Commission (2014b) Impact assessment accompanying the document "a policy framework for climate and energy in the period from 2020 up to 2030". SWD (2014) 15 final

European Council (2009) Decision 406/2009/EC of the European Parliament and of the Council of 23 April 2009 on the effort of Member States to reduce their Greenhouse gas emissions to meet the Community's greenhouse gas emission reduction commitments up to 2020. Official Journal of the European Union, L140/63

European Council (2014) Conclusions on 2030 climate and energy policy framework. European Council, (23 and 24 October 2014), [SN 79/14]

FAO (2016) FAOSTAT emissions database, agriculture, agriculture total. http://www.fao.org/faostat/en/\#data/GT (20 November 2016)

Frankel J (2008) Global environmental policy and global trade policy. Discussion paper 08-14. Harvard John F. Kennedy School of Government, Cambridge, MA http://www.belfercenter. org/sites/default/files/legacy/files/Frankel2Web.pdf

GAINS database (2013) Greenhouse gas and air pollution interactions and synergies. International Institute for Applied Systems Analysis (IIASA), http://www.iiasa.ac.at/web/home/research/researchPrograms/GAINS. en.html

Garnett T (2011) Where are the best opportunities for reducing greenhouse gas emissions in the food system (including the food chain)? Food Policy 36:S23-S32

Gernaat DEHJ, Calvin K, Lucas PL et al (2015) Understanding the contribution of non-carbon dioxide gases in deep mitigation scenarios. Global Environ Chang 33:142-153

Hedenus F, Wirsenius S, Johansson DJA (2014) The importance of reducing meat and dairy consumption for meeting stringent climate change targets. Clim Chang 124:79-91

Henderson B, Falcucci A, Mottet A, Early L, Werner B, Steinfeld H, Gerber P (2017) Marginal costs of abating greenhouse gases in the global ruminant livestock sector. Mitig Adapt Strateg Glob Change 22:199-224

Himics M, Artavia M, Hélaine S, Boysen O (2014) Calibrating the CAPRI and ESIM models to the mid-term commodity market outlook of the European Commission. JRC Technical Reports, European Commission. Joint Research Centre, Seville

Höglund-Isaksson L, Winiwarter W, Purohit P (2013) Non-CO2 greenhouse gas emissions, mitigation potentials and costs in the EU-28 from 2005 to 2050, GAINS model methodology. IIASA, Laxenburg

Hristov AN, Oh J, Firkins JL, Dijkstra J, Kebreab E, Waghorn G, Makkar HPS, Adesogan AT, Yang W, Lee C, Gerberc PJ, Henderson B, Tricarico JM (2013) Mitigation of methane and nitrous oxide emissions from animal operations: I. A review of enteric methane mitigation options. J Anim Sci 91:5045-5069

IPCC (2006) 2006 IPCC Guidelines for National Greenhouse Gas Inventories. Prepared by the National Greenhouse Gas Inventories Programme. In: Eggleston HAS, Biennia L, Miwa K, Negara T, Tanabe K (eds) . Published: IGES, Japan

Jansson T, Perez Dominguez I, Weiss F (2010) Estimation of greenhouse gas coefficients per commodity and world region to capture emission leakage in European Agriculture. Paper presented at the 119th EAAE seminar "Sustainability in the Food Sector", Capri, Italy

Leip A, Weiss F, Wassenaar T, Perez I, Fellmann T, Loudjani P, Tubiello F, Grandgirard D, Monni S, Biala K (2010) Evaluation of the livestock sector's contribution to the EU greenhouse gas emissions (GGELS). European Commission, Joint Research Centre, Brussels

MacLeod M, Eory V, Gruère G, Lankoski J (2015) Cost-effectiveness of greenhouse gas mitigation measures for agriculture: a literature review. OECD Food, Agriculture and Fisheries papers, no. 89. OECD Publishing, Paris

OECD-FAO (2012) OECD-FAO agricultural outlook 2012-2021. Organisation for Economic Cooperation and Development, Paris, and Food and Agricultural Organisation of the United Nations. OECD Publishing and FAO, Rome

Pérez Domínguez I (2006) Greenhouse gases: inventories, abatement costs and markets for emission permits in European agriculture - a modelling approach. Peter Lang, Frankfurt a.M

Pérez Domínguez I, Fellmann T (2015) The need for comprehensive climate change mitigation policies in European agriculture. Euro Choices 14(1):11-16

Pérez Domínguez I, Fellmann T, Witzke HP, Jansson T, Oudendag D, Gocht A, Verhoog D (2012) Agricultural GHG emissions in the EU: an exploratory economic assessment of mitigation policy options. JRC Scientific and Policy Reports. European Commission, Seville

Reisinger A, Havlik P, Riahi K, van Vliet O, Obersteiner M, Herrero M (2013) Implications of alternative metrics for global mitigation costs and greenhouse gas emissions from agriculture. Clim Chang 117:677-690 
Richards MB, Wollenberg E, Buglion-Gluck S (2015) Agriculture's contributions to national emissions. CCAFS info brief. CGIAR Research Program on Climate Change. Agriculture and Food Security (CCAFS), Copenhagen

Richards M, Bruun TB, Campbell B, Gregersen LE, Huyer S, Kuntze V, Madsen STN, Oldvig MB, Vasileiou I (2016) How countries plan to address agricultural adaptation and mitigation: an analysis of Intended Nationally Determined Contributions. CCAFS dataset version 1.3. Copenhagen, Denmark: CGIAR Research Program on Climate Change. Agriculture and Food Security (CCAFS), Copenhagen

Scott K, Barrett J (2015) An integration of net imported emissions into climate change targets. Environ Sci Pol 52:150-157

Smith P, Martino D, Cai Z, Gwary D, Janzen H, Kumar P, McCarl B, Ogle S, O’Mara F, Rice C, Scholes B, Sirotenko O (2007) Agriculture. In: Metz B et al (eds) Climate change 2007: mitigation. Contribution of working group III to the fourth assessment report of the IPCC. Cambridge University Press, Cambridge

Smith P, Bustamante M, Ahammad H, Clark H, Dong H, Elsiddig EA, Haberl H, Harper R, House J, Jafari M, Masera O, Mbow C, Ravindranath NH, Rice CW, Robledo Abad C, Romanovskaya A, Sperling F, Tubiello F (2014) Agriculture, forestry and other land use (AFOLU). In: Edenhofer et al (eds) Climate change 2014: mitigation of climate change. Contribution of working group III to the fifth assessment report of the IPCC. Cambridge University Press, Cambridge

Somanathan E, Sterner T, Sugiyama T, Chimanikire D, Dubash NK, Essandoh-Yeddu J, Fifita S, Goulder L, Jaffe A, Labandeira X, Managi S, Mitchell C, Montero JP, Teng F, Zylicz T (2014) National and sub-national policies and institutions. In: Edenhofer et al (eds) Climate change 2014: mitigation of climate change. Contribution of working group III to the fifth assessment report of the IPCC. Cambridge University Press, Cambridge

Stavins R, Zou J, Brewer T, Conte Grand M, den Elzen M, Finus M, Gupta J, Höhne N, Lee MK, Michaelowa A, Paterson M, Ramakrishna K, Wen G, Wiener J, Winkler H (2014) International Cooperation: agreements and instruments. In: Edenhofer et al (eds) Climate change 2014: mitigation of climate change. Contribution of working group III to the fifth assessment report of the IPCC. Cambridge University Press, Cambridge

Stehfest E (2014) Food choices for health and planet. Nature 515:501-502

Stehfest E, Bouwman L, van Vuuren DP, den Elzen MGJ, Eickhout B, Kabat P (2009) Climate benefits of changing diet. Clim Chang 95:83-102

Tilman D, Balzer C, Hill J, Befort BL (2011) Global food demand and the sustainable intensification of agriculture. PNAS 108(15):20260-20264

UNFCCC (2016) Intended Nationally Determined Contributions (INDCs). http://www4.unfecc. int/Submissions/INDC/Submission\%20Pages/submissions.aspx (accessed on 10 October 2016).

Van Doorslaer B, Witzke P, Huck I, Weiss F, Fellmann T, Salputra G, Jansson T, Drabik D, Leip A (2015) An economic assessment of GHG mitigation policy options for EU agriculture (EcAMPA). JRC Technical Reports. European Commission, Seville

Vermont B, De Cara S (2010) How costly is mitigation of non-CO2 greenhouse gas emissions from agriculture? Ecol Eco 69(7):1373-1386

Westhoek H, Lesschen JP, Rood T, Wagner S, De Marco A, Murphy-Bokern D, Leip A, van Grinsven H, Sutton MA, Oenema O (2014) Food choices, health and environment: effects of cutting Europe's meat and dairy intake. Global Environ Chang 26:196-205

Witzke P, Van Doorslaer B, Huck I, Salputra G, Fellmann T, Drabik D, Weiss F, Leip A (2014) Assessing the importance of technological non-CO2 GHG emission mitigation options in EU agriculture with the CAPRI model. Paper presented at the EAAE 2014 Congress 'Agri-Food and Rural Innovations for Healthier Societies' August 26 to 29, 2014, Ljubljana, Slovenia

Wollenberg E, Richards M, Smith P, Havlík P, Obersteiner M, Tubiello FN, Herold M, Gerber P, Carter S, Reisinger A, van Vuuren DP, Dickie A, Neufeldt H, Sander BO, Wassmann R, Sommer R, Amonette JE, Falcucci A, Herrero M, Opio C, Roman-Cuesta RM, Stehfest E, Westhoek H, Ortiz-Monasterio I, Sapkota T, Rufino MC, Thornton PK, Verchot L, West PC, Soussana JF, Baedeker T, Sadler M, Vermeulen S, Campbell $\mathrm{BM}$ (2016) Reducing emissions from agriculture to meet the $2{ }^{\circ} \mathrm{C}$ target. Glob Change Biol 22:3859-3864 